\title{
The cytogenetic parameters of Pinus sylvestris L. under conditions of the Far North of Russia (Karelia)
}

\author{
Roman Viktorovich Ignatenko ${ }^{1,2 *}$, Lyubov Alexandrovna Efimova ${ }^{1}$, \\ Ksenia Mikhailovna Nikerova ${ }^{2}$
}

${ }^{1}$ Laboratory for Plant Biotechnology, Karelian Research Centre of the Russian Academy of Sciences, Pushkinskaya St. 11, Petrozavodsk 185910, Russia

${ }^{2}$ Department of General Chemistry, Petrozavodsk State University, Lenin Av. 33, Petrozavodsk 185910, Russia

\begin{abstract}
Ignatenko, R.V., Efimova, L.A., Nikerova, K.M., 2022. The cytogenetic parameters of Pinus sylvestris L. under conditions of the Far North of Russia (Karelia). Folia Oecologica, 49 (1): 61-69.

The cytogenetic analysis of the Pinus sylvestris L. seed progeny in the forests of the northern taiga in the Far North of Russia conditions was carried out. Two Pinus sylvestris populations growing in Ambarnskoy and Pyaozerskoy forest divisions of Loukhsky district of Karelia Republic were studied. The number of chromosomes, the frequency and types of mitosis disturbances at the metaphase, anaphase and telophase (as a percentage of the total number of dividing cells at the same stages), and the frequency of micronuclei occurrence, as well as the laboratory seed germination, were studied. As a result of the study, it was found that $50-56 \%$ of the studied sprouts were mixoploid. Analysis of mitosis showed that the root meristem of the studied samples contained cells with various pathologies; simultaneously, the frequency of mitosis pathologies in the Ambarnskoy population was significantly higher than in the Pyaozerskoy one. It amounted to 6.8 \pm 0.4 and $4.9 \pm 0.4 \%$, respectively. Nine types of abnormalities were identified; chromosome overrun and bridges prevailed. Micronuclei were registered in 35-38\% of the studied Pinus sylvestris sprouts. At the same time, the proportion of cells with micronuclei in the Ambarnskoy population was 2-fold higher than in the Pyaozerskoy one and averaged $0.12 \pm 0.03 \%$ and $0.07 \pm 0.02 \%$, respectively.
\end{abstract}

\section{Keywords}

cytogenetics, germination, micronuclei, mitotic pathologies, mixoploidy, Scots pine, taiga ecosystems

\section{Introduction}

Forest ecosystems of the northern taiga subzone in the extreme conditions of the Far North perform environmentforming and environment-protective functions; also, they are natural environment stabilizers (TsvetKov, 2006; TsvetKov and Brovina, 2017). Northern forests can degrade for a long time; lose their stability and ecological potential under stressful external influences (TsveTKov, 2006; Gromtsev and Petrov, 2016). It should be noted that when such forests are destroyed, the entire biota is degraded, delicate chains of the fragile matter biological cycles are destroyed (TsvetKov and Brovina, 2017). In this regard, it is necessary to estimate these ecosystems using the most effective and adequate methods.

Changes in the genetic material are among the most significant from the numerous biological effects that are recorded in response to environmental factors (DAEV et al., 2015). They appear at the early developmental stages of the body's reaction and can be transmitted to subsequent

*Corresponding author: 
generations. The genome is a labile system that responds quickly to a tiny change in the environment. Therefore, the cytogenetic method is one of the most sensitive ways to evaluate the impact of unfavourable external factors on the environment effectively (Ehkologicheskii monitoring. Metody biologicheskogo monitoringa. Chast' 2, 1995; Butorina and KalaYev, 2000; KalashniK, 2008; SLuCHYK et al., 2014; DAEv et al., 2015).

Scots pine (Pinus sylvestris L.) is among conifers that are considered a promising species for environment monitoring (Prus-GŁowACKI et al., 2006; BUtORINA et al., 2007, 2008; KALASHNIK, 2008; MASHKINA et al., 2009). This woody plant is included in the reference list of biological species, which are the basis for the modern concept of radiation protection of the environment (GERAS'KIN et al., 2018). The reproductive organs of gymnosperms are the most sensitive to damaging influences because of their complex organization and long generative cycle. Seeds are ripening within 28 months in P. sylvestris, and it contributes to the accumulation in unspecialized initial seed cells of a sufficient amount of DNA damage to fix an external effect. Their implementation in aberration occurs mainly in the first mitosis (GERAS'KIN et al., 2003).

The aim of the study was the cytogenetic assessment of the seed progeny of $P$. sylvestris from two populations located in different soil and climatic conditions in the Far North of Russia. The number of chromosomes, the frequency and types of pathologies of mitosis at the stages of metaphase, ana-telophase, the frequency of micronuclei occurrence, and laboratory germination of seeds were used as biomarkers.

\section{Materials and methods}

The cytogenetic studies of $P$. sylvestris were carried out in two populations (Ambarnskoy and Pyaozerskoy forest divisions) located in the northern taiga subzone in Loukhsky district of Republic of Karelia (Russia) (Fig. 1). On the territory of the Ambarnskoy forest division, seeds were collected in the pine forest Vaccinium vitisidaea, in which pine constituted $80 \%$ of the tree layer (Table 1). In Pyaozerskoy forest division, material for the study was collected in the pine forest Vaccinium myrtillus, where pine accounted for $70 \%$ of the stand, spruce $-20 \%$, birch $-10 \%$. These forests belong to the IV and V bonitet classes, which characterizes them as low-productive forests. The Ambarnskoy forest division is located in the northern part of the Karelian Coast subregion (MaanselkaBelomorsky region) (Atlas Karel'skoi ASSR, 1989). This subdistrict is characterized by the most severe climatic conditions (Table 2). There is cold long winter here, and the sum of temperatures for the growing season above 5 ${ }^{\circ} \mathrm{C}$ is $1,350-1,500{ }^{\circ} \mathrm{C}$. The Pyaozerskoy forest division is located in more favourable conditions of the Northern Lake agroclimatic region. Winter is harsh and extended in this area, and the growing season is cold and short (Table 2).

Population seed mixtures of $P$. sylvestris, harvested in 2018, were used as material for the study. They were provided by the Karelian Forest Seed Station department of the Forest Protection Center of the Leningrad Region (FBI «Roslesozashchita»).

The seeds were spread out evenly on two-layer wet filter paper in Petri dishes and germinated at room temperature for 15 days to evaluate the laboratory germination. The laboratory germination (\%) was determined as the number of germinated seeds from the total number (30 seeds) of seeds in each Petri dish. 9 Petri dishes were used for each place of the collection of seeds.

The root tips of germinated seeds, which reached $5-15 \mathrm{~mm}$ in length, were used for the cytogenetic analysis. The number of chromosomes, the frequency and types of pathologies of mitosis at the metaphase, ana-telophase

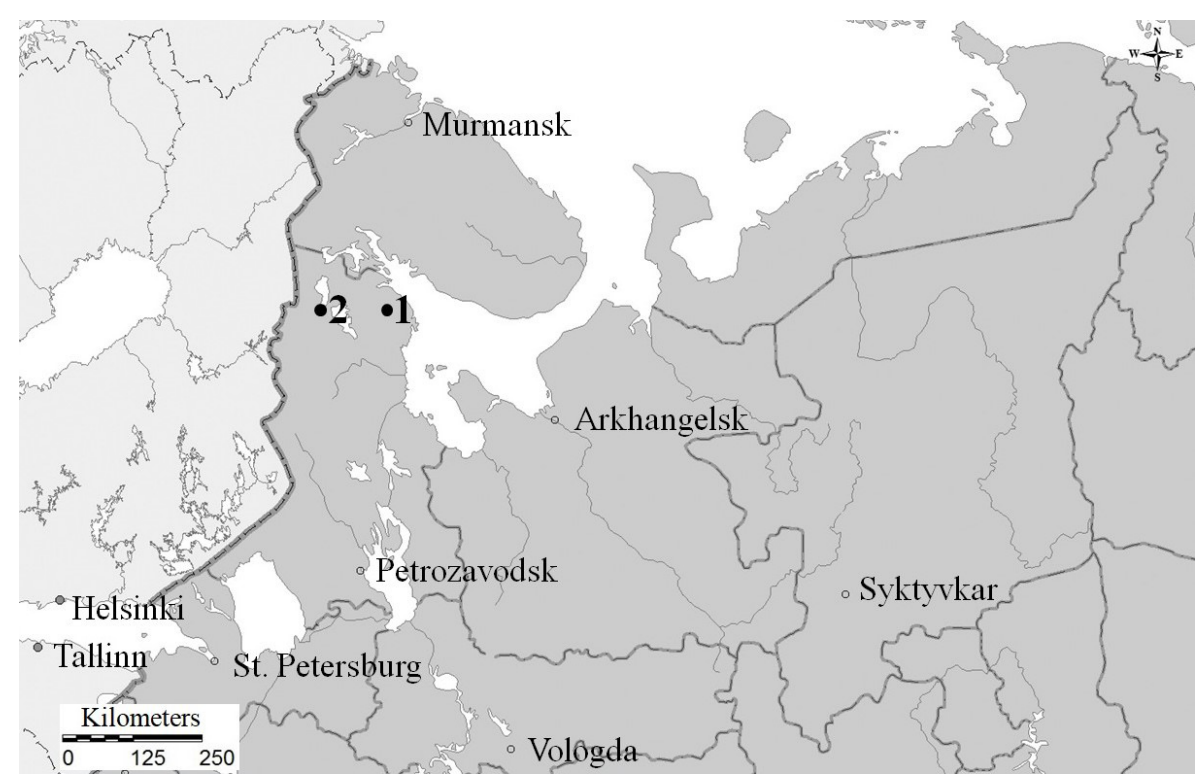

Fig. 1. Schematic map of the study area. Places of the experimental material collection: 1 - Ambarnskoy forest division, 2 - Pyaozerskoy forest division (map was created using MapInfo). 
Table 1. The characteristic of places for the experimental material collection

\begin{tabular}{|c|c|c|c|c|c|}
\hline No & Forest division & Forest type & $\begin{array}{l}\text { Geographic } \\
\text { latitude }\end{array}$ & Tree composition, $\%$ & Bonitet class \\
\hline 1 & Ambarnskoy & $\begin{array}{l}\text { Pine forest } \\
\text { Vaccinium } \\
\text { vitis-idaea }\end{array}$ & $\begin{array}{l}65.90112^{\circ} \mathrm{N} \\
33.69724^{\circ} \mathrm{E}\end{array}$ & $80 \mathrm{P} 20 \mathrm{~B}$ & IV \\
\hline 2 & Pyaozerskoy & $\begin{array}{l}\text { Pine forest } \\
\text { Vaccinium } \\
\text { myrtillus }\end{array}$ & $\begin{array}{l}65.73774^{\circ} \mathrm{N} \\
30.86345^{\circ} \mathrm{E}\end{array}$ & 70P20S10B & $\mathrm{V}$ \\
\hline
\end{tabular}

Tree species ( $\mathrm{S}$ - spruce, $\mathrm{B}$ - birch, $\mathrm{P}$ - pine).

Table 2. Brief comparative characteristics of the climatic conditions of the Karelian coast subdistrict and the Northern Lake district (Atlas Karel'skoi ASSR, 1989)

\begin{tabular}{lll}
\hline \multirow{2}{*}{ Climatic conditions } & Agroclimatic area & \\
\cline { 2 - 3 } & Karelian coast subdistrict & Northern Lake district \\
\hline Average air temperature $\left({ }^{\circ} \mathrm{C}\right):$ & & \\
the coldest month (January) & $(-10.5)-(-11.5)$ & $(-11.5)-(-12.0)$ \\
the warmest month $(\mathrm{July})$ & $(+14.0)-(+14.5)$ & $(+14.5)-(+15.0)$ \\
frost-free season length (days) & $105-115$ & $85-95$ \\
\hline The average sum of the effective temperatures $\left({ }^{\circ} \mathrm{C}\right):$ & & $1,450-1,650$ \\
values above +5 & $1,350-1,500$ & $1,000-1,200$ \\
values above +10 & $\sim 1,000$ & $550-600$ \\
annual precipitation (mm/year) & $550-575$ & $150-225$ \\
the precipitation during the growing season, $\mathrm{mm}$ & $135-150$ & $165-170$ \\
number of days with snow cover & $170-180$ & \\
\hline
\end{tabular}

( $\%$ of the total number of dividing cells at the same stages), the frequency of micronuclei were among the studied cytogenetic parameters (GORYACHKINA and SIZYKH, 2012; MASHKINA et al., 2012). So, the root tips were fixed in an alcohol-acetic mixture (96\% ethyl alcohol and glacial acetic acid volume ratio of $3: 1$ ) for $24 \mathrm{~h}$ (PRAVDIN et al., 1972; PUKHAL'sKIY et al., 2007). Squashed preparations were prepared according to the standard methods (Pravdin et al., 1972). The material was treated with a $1 \%$ aqueous solution of colchicine for five $\mathrm{h}$ and kept in a $4 \%$ solution of ammonium iron sulphate for $10-15 \mathrm{~min}$ and stained with $1 \%$ aceto-hematoxylin before fixation to count the number of chromosomes. The preparations were examined using a Carl Zeiss Primo Star microscope (Germany) at 40× image magnification. ADFstd 10 digital eyepiece camera was used for photomicrographs. Eighteen seedlings from the Ambarnskoy forest division (345 metaphase plates) and sixteen from the Pyaozerskoy forest division (322 metaphase plates) treated with $1 \%$ colchicine solution for each population were analyzed, as well as 45 and 46 seedlings without processing were also were analyzed, respectively.

Statistical processing was performed using the statistical software package Microsoft Excel and PAST (version 4.0). Before starting the statistical analysis, raw data was initially tested for normality using the Shapiro-
Wilk test. The significance of differences between variants was estimated by Mann-Whitney U-test (IVANTER and Korosov, 2011). The difference was considered significant with $p<0.01$. Regression analysis was carried out using a linear model: $\mathrm{y}=\mathrm{aX}+\mathrm{b}$.

\section{Results}

\section{Laboratory seed germination}

The study of laboratory seed germination of $P$. sylvestris did not reveal a significant difference between the two populations. So, this indicator for seeds from the Ambarnskoy forest division averaged $76.0 \pm 3.1 \%$ (the coefficient of variation was $12.7 \%$ ), and for the Pyaozerskoy forest division $-80.4 \pm 3.2 \%$ (the coefficient of variation is $11.8 \%$ ).

\section{Karyological research}

The root meristem study of the seed progeny of $P$. sylvestris, treated with $1 \%$ colchicine solution, showed that the diploid set contained 24 chromosomes (Fig. 2a). Some seedlings had polyploid (Fig. 2b) and aneuploid cells $(2 n=22,2 n=23,2 n=25,2 n=26)$ (Fig. $2 c)$, while 
the proportion of such cells was higher in plants from the Ambarnskoy population (Fig. 3). Mixoploid seedlings in the studied samples were observed with a frequency of $50-56 \%$. Chromosomal rearrangements such as ring (Fig. 4a) and dicentric chromosomes (Fig. 4b) were registered in some metaphase plates. B-chromosomes were detected very rarely (Fig. 4c).

\section{Study of mitosis pathologies}

The analysis of seedlings' mitosis that was not treated with colchicine showed that the root meristem contained cells with various pathologies at the stages of metaphase and ana-telophase in all studied plants. The «frequency of mitotic disturbances», which reflects the DNA damage degree, is one of the cytogenetic method's most sensitive and informative criteria (Kalayev, 2009; PARdayeva et al., 2017). It was found that this indicator for P. sylvestris should not exceed 5\% in Central Russia (Butorina et al., 2001). The level of spontaneous mutation exceeded the established norms and was $6.8 \pm 0.4 \%$ in the seedlings of $P$. sylvestris from the Ambarnskoy population. This indicator was significantly lower (U-test, $p<0.01$ ) and was $4.9 \pm 0.4 \%$ in plants from the Pyaozerskoy population.
The spectrum of mitotic disturbances was taken into account during the cytogenetic analysis. Nine types of disturbances were identified, which were divided into three groups (KALASHNiK, 2008; PARDAYEVA et al., 2017). The first group included structural rearrangements of chromosomes - chromosome fragmentation in metaphase and anaphase (Fig. 5a), bridges in the anaphase (Fig. $5 \mathrm{~b}$ ) and ring chromosomes in metaphase (Fig. 5c). The second group consisted of genomic aberrations: overrun of chromosomes in metaphase and anaphase (Fig. 5d), isolation of chromosomes and chromosome groups in metaphase and anaphase (Fig. 5e), lagging chromosomes in anaphase (Fig. 5f), multipolarity (Fig. 5g) and chaotic divergence of chromosomes in the ana-telophase (Fig. 5h). The third group - complex (multiple) violations - bridges + chromosome overrun (Fig. 5i), bridge + chromosome lag in the ana-telophase, etc.

The chromosome overrun and bridges were the predominant abnormalities in the whole spectrum of mitotic disturbances in the studied populations (Fig. 6). It was found that structural aberrations of chromosomes were 2-fold more frequent in seedlings from the Ambarnskoy population than in the plants from the Pyaozerskoy forest division. (a)

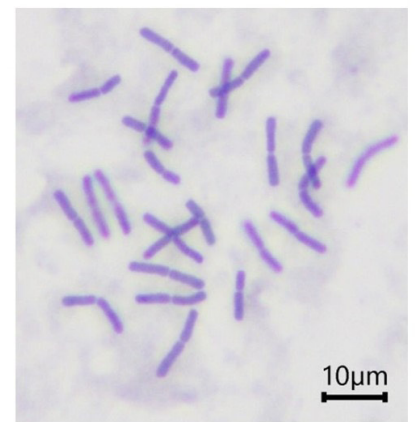

(b)

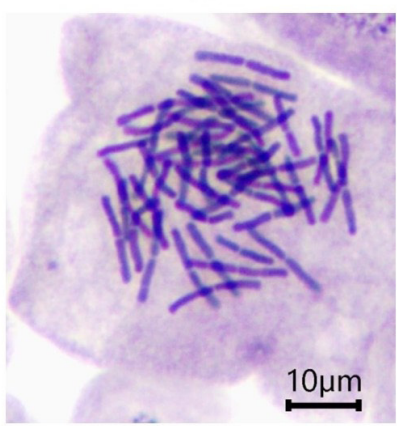

(c)

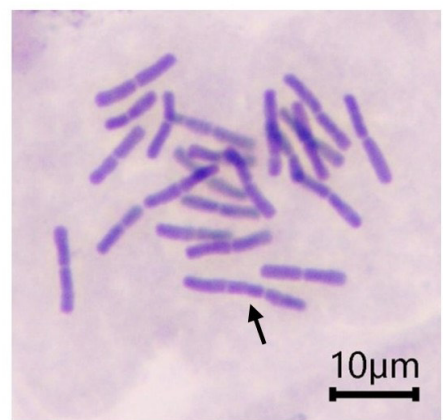

Fig. 2. Metaphase plates with different numbers of chromosomes in the root meristem of the Pinus sylvestris seed progeny: diploid (a), polyploid (b) and aneuploid $(2 \mathrm{n}-1=23$, dicentric chromosome is indicated by an arrow) (c) cells.

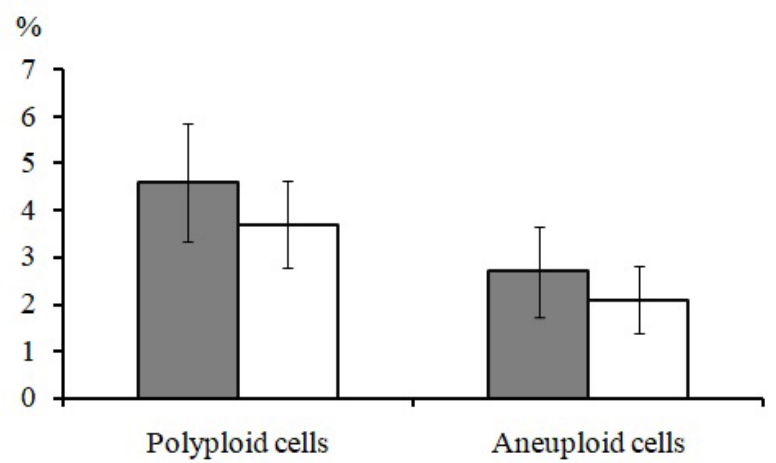

Fig. 3. The proportion of polyploid and aneuploid cells in the root meristem of the seed progeny of Pinus sylvestris from Ambarnskoy (gray column, $\mathrm{n}=345$ metaphase plates) and Pyaozerskoy (white column, $\mathrm{n}=322$ metaphase plates) forest divisions. Bars represent standard error of the mean. 


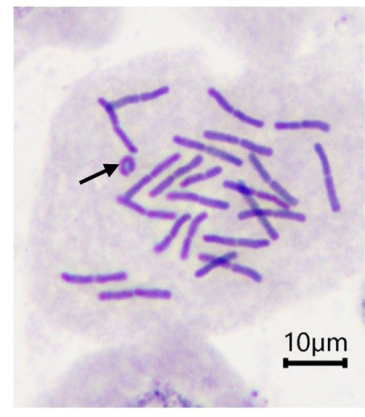

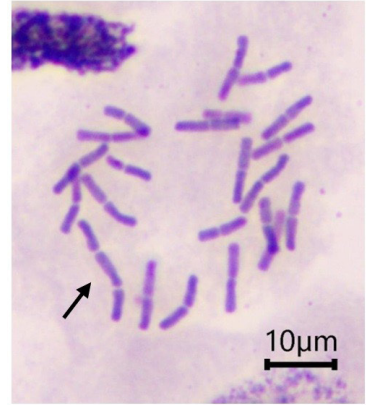

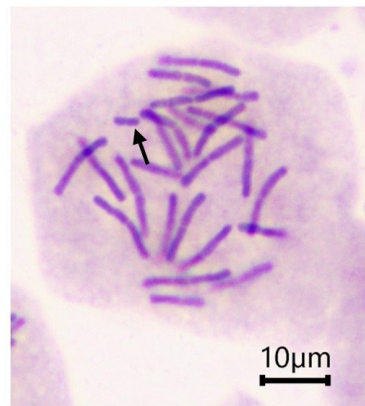

Fig. 4. Metaphase plates in the root meristem of the seed progeny of Pinus sylvestris with ring (a), dicentric (b) and accessory supernumerary (c) chromosomes.

(a)

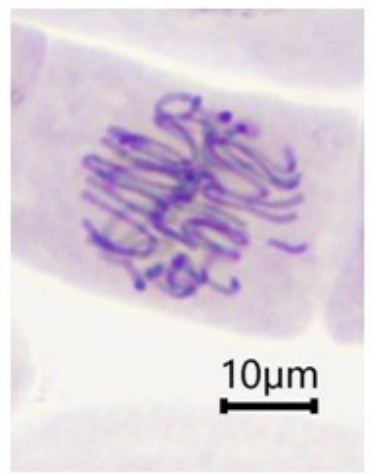

(d)

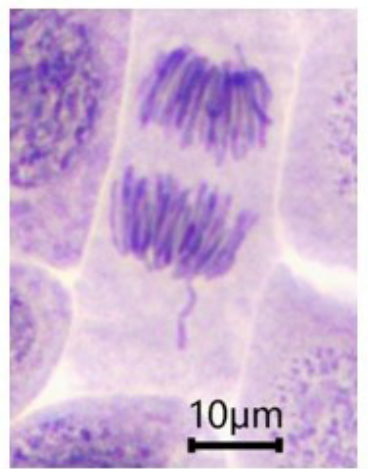

(g)

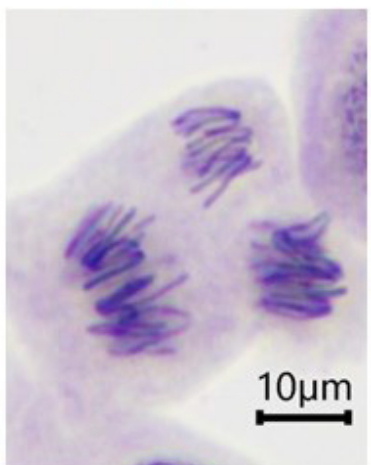

(b)

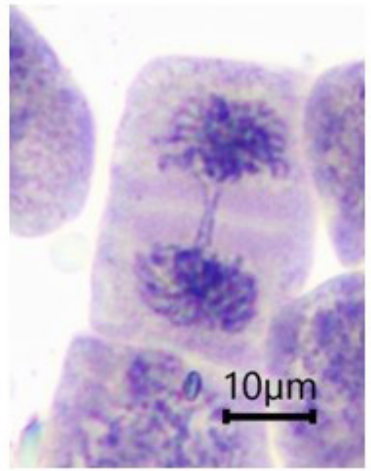

(e)

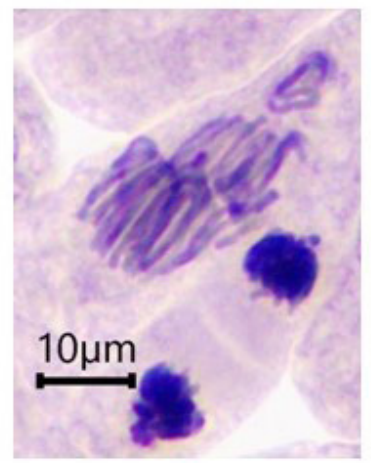

(h)

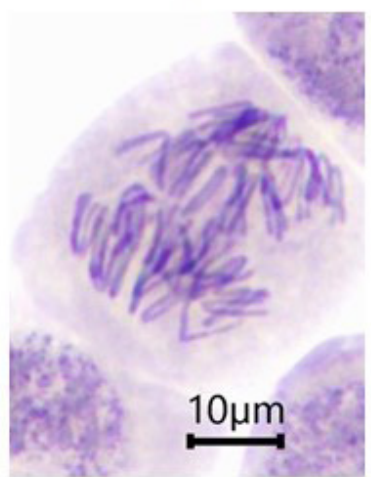

(c)

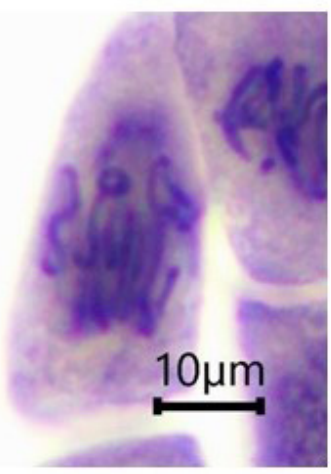

(f)

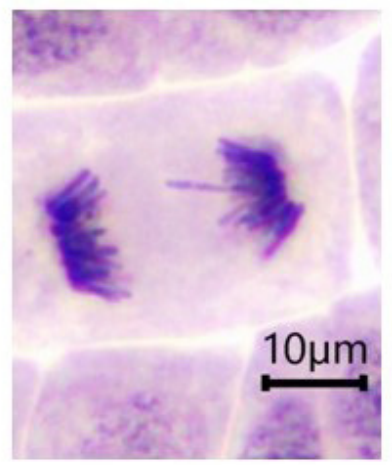

(i)

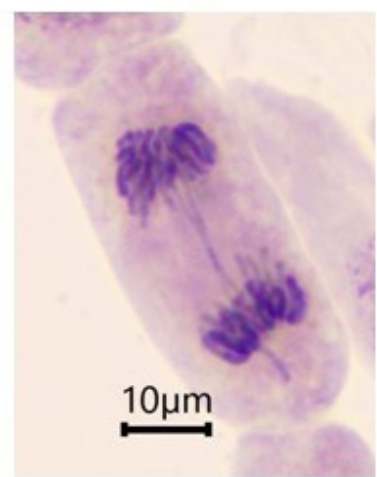

Fig. 5. Types of mitotic disturbances that were found in the root meristem of the seed progeny of Pinus sylvestris: $\mathrm{a}$ - chromosome fragment in metaphase, $\mathrm{b}$ - double bridge in telophase, $\mathrm{c}$ - ring chromosome in metaphase, $\mathrm{d}$ - chromosome overrun in anaphase, $\mathrm{e}$-isolation of a group of chromosomes in metaphase, $\mathrm{f}$ - lagging in anaphase, $\mathrm{g}$ - multipolar mitosis in anaphase, $\mathrm{h}-$ chaotic divergence of chromosomes in anaphase, $\mathrm{i}-$ complex disturbances: bridge + running overrun in anaphase. 


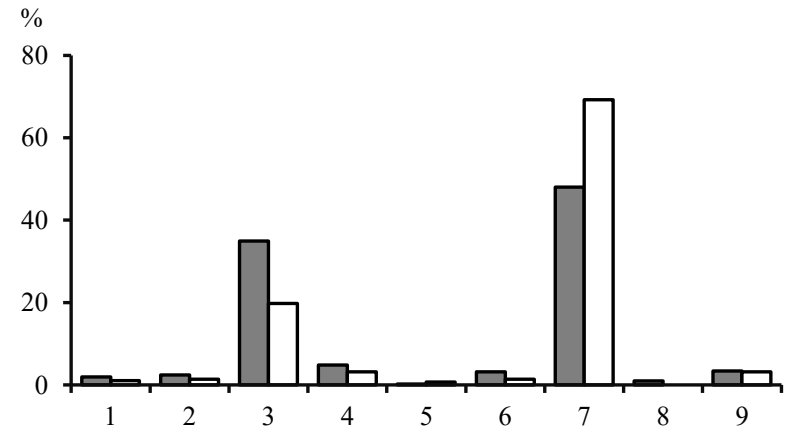

Fig. 6. The spectrum of mitosis disturbances at the stages of metaphase and ana-telophase in the root meristem of Pinus sylvestris seedlings from Ambarnskoy (gray column) and Pyaozerskoy (white column) forest divisions. The numbers indicate the types of mitosis disturbances: 1 - ring chromosomes in metaphase, 2 - chromosome fragmentation in metaphase and anaphase, 3 - bridges in the anaphase, 4 - chromosome lagging in anaphase, 5 - multipolarity in ana-telophase, 6 chromosome isolation and groups of chromosomes in metaphase and anaphase, 7 - overrun of chromosomes in metaphase and anaphase, 8 - chaotic divergence of chromosomes in the anaphase, 9 - complex (multiple) violations.

\section{Micronucleus test}

Micronuclei were found in cells at the interphase stage in $35-38 \%$ of the studied seedlings. It is important to note that in the Ambarnskoy population, the proportion of cells with micronuclei was 2-fold higher than in the Pyaozerskoy population and averaged $0.12 \pm 0.03 \%$ and $0.07 \pm 0.02 \%$, respectively. As a result of the pooled sample analysis, the relationship was revealed the higher the frequency of mitotic disturbances was, the higher the proportion of cells with micronuclei was (Fig. 7).

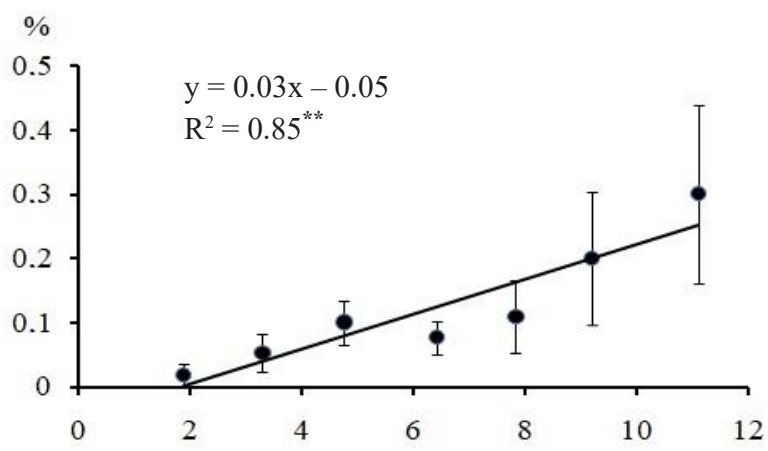

Fig. 7. Change in the proportion of cells with micronuclei with an increase in the frequency of mitotic disturbances in the root meristem of Pinus sylvestris seedlings from the northern taiga populations of Karelia. Bars represent standard errors of the average meanings $(* * p<0.01) . \mathrm{R}^{2}$ is the coefficient of determination.

\section{Discussion}

Cytogenetic monitoring is one of the modern methods for evaluating the influence of environmental factors on organisms and forecasting the rate of the mutation process (KvitKo et al., 2011). Abiotic stress induces anomalies in the mitotic cell cycle and chromosomes (CARVALHO et al., 2018; Reis et al., 2018; CARvalho et al., 2020). The complex use of the cytogenetic parameters on the specific test object makes it possible to determine the limits of objects' sensitivity and adequate environment estimation. Karyotype, frequency and types of mitotic disturbances, number and proportion of cells with micronuclei were criteria analyzed within our study.

The karyological analysis showed that mixoploidy was revealed in half of the studied samples. Some researchers believe that mixoploidy is associated with the adaptation of plants to unfavourable environmental conditions (Kunakh, 1995; Sedel'Nikova et al., 2010; Kunakh, 2011). Thus, the appearance of polyploid cells can be considered as one of the regulatory mechanisms that allow maintaining a certain level of population resistance in extreme environmental conditions (Muratova and Sedel'NiKova, 2004).

Dicentric chromosomes in the cells of the root meristem of $P$. sylvestris appeared due to asymmetric interchromosomal translocations (NemTSEva, 1970). The redistribution of the genetic material between chromosomes occurred here and led to an additional reservoir of variability and a restructuring of the regulatory system of the genome (Muratova and Sedel'nikova, 2004; Stimpson et al., 2012). However, at the same time, ring chromosomes led to the loss of gene material (Nemtseva, 1970).

Single cells with a B chromosome were recorded during the study of metaphase plates of the root meristem of $P$. sylvestris. The literature data contain information about an increase in the plants' adaptability with additional chromosomes found in the karyotype (HIzUME et al., 1988). Thus, it was found that the presence of B chromosomes could affect the process of seed germination (VLADIMIROVA and Muratova, 2005). For example, seeds collected from the trees with B chromosomes had, on average, one day earlier germination in Picea glauca (TEOH and ReEs, 1977). However, there is still no consensus on their biological role (Butorina et al., 1979; Vladimirova and Muratova, 2005).

The analysis of the frequency of mitosis disturbances revealed that the proportion of aberrant cells in the seed progeny of $P$. sylvestris from the Ambarnskoy population was significantly higher than in the Pyaozerskoy population. Moreover, it was probably associated with the habitat's different soil and climatic conditions (Atlas Karel'skoi $A S S R$, 1989). It should be noted that the proportion of structural disorders in the total spectrum of mitosis pathologies was $39 \%$ in plants from the Ambarnskoy forest division, while it was $22 \%$ in the Pyaozerskoy one. The increase in structural disorders was due to an increase in the proportion of cells with bridges. Studies of the cytogenetic parameters of the seed progeny of Betula pendula Roth and Quercus robur L. under stressful conditions have shown (KALAYEV, 2009) an increase in the frequency of bridges in the spectrum of mitotic pathologies can be an indicator of the activity of the repair systems. 
Despite this fact, many cells with micronuclei were found in the root meristem of the seed progeny of P. sylvestris from the Ambarnskoy population. According to the studies by Muratova and Sedel'NiKova, 2004, micronuclei refer to specific damages of the «hard» type, which, as a rule, are lethal for cells and can lead to plant inhibition. Most of the disturbances during mitosis are eliminated with the help of the repair systems (GORYACHKINA and SIZYKH, 2012). However, the accumulation of unrepaired disorders can significantly impact the stress factors on the organism, destabilising the mitotic apparatus work. The mechanism of postmitotic micronucleation transfers latent genome damage accumulated for some time into morphologically identifiable cellular forms (IL'INSKIKH, 1988). We found that with an increase in the frequency of mitotic pathologies (especially starting from $8 \%$ ), the proportion of cells with micronuclei increases rapidly in the total sample (Fig. 7), and this can lead to cytogenetic instability of cell populations (IL'INSKIKH et al., 1992).

Interestingly, despite the extreme growing conditions, most of the seeds collected on the territory of the Ambarnsky and Pyaozersky district forestries normally germinated in laboratory conditions. The study of the cytogenetic characteristics of the seed progeny of $P$. sylvestris in the south of eastern Siberia in plants from Shirinsky Bor (Republic of Khakassia) showed that the value of this indicator was $47.9 \pm 4.3 \%$, while in the control one (Usmansky Bor, Voronezh region) was 88.3 $\pm 2.9 \%$ (Mashkina et al., 2012). At the same time, the frequency of the mitoses disturbances and micronuclei occurrence was higher in Shirinsky Bor $(2.8 \pm 0.4 \%$ and $0.6 \pm 0.1 \%$, respectively) than in Usmansky one $(0.8 \pm$ $0.1 \%$ and $0.003 \pm 0.002 \%$, respectively). Studies carried out on the territory of Poland showed that the germination rate of $P$. sylvestris seeds was $81 \%$ from phytocenoses not susceptible to contamination with heavy metals (National Park of Wielkopolska) and significantly lower for seeds collected from sensitive $(54.2 \%)$ and tolerant $(69.2 \%)$ of trees located near the zinc smelter (PrUs-GŁOWACKI et al., 2006).

\section{Conclusions}

Thus, a cytogenetic study of the seed progeny of $P$. sylvestris from two populations of the Ambarnsky and Pyaozersky district forestries located in the northern taiga subzone of Karelia made it possible to reveal the differences between them. In the root meristem of $P$. sylvestris seedlings from the Ambarnsky district forestry, the proportion of cells with various types of mitotic pathologies significantly (1.4 times) exceeded that in plants from the Pyaozersky population, which was probably due to more extreme environmental conditions. The impact of stress factors also led to the unrepaired aberrations accumulation, which, most likely, found its expression in an increase in the proportion of cells with micronuclei. However, despite the revealed cytogenetic abnormalities in the root meristem of two populations, laboratory seed germination remained at a reasonably high level (75-80\%). The presented data indicate an active work of the repair system in P. sylvestris seedlings and an increase in the resistance of populations to extreme growing conditions in the Far North of Russia. In this regard, we recommend carrying out cytogenetic monitoring of northern ecosystems in places of the intense anthropogenic impact associated with the development of industry and agriculture.

\section{Funding and acknowledgement}

All assays were performed at the Core Facility of the Karelian Research Centre RAS. The study was carried out under a world-class scientific and educational centre called Russian Arctic: New Materials, Technologies, and Research Methods.

The study was carried out under state order to the Karelian Research Centre of the Russian Academy of Sciences (0185-2019-0093). The authors are grateful to the department the Karelian Forest Seed Station of the Forest Protection Center of the Leningrad Region (FBI «Roslesozashchita») for the seeds of Pinus sylvestris provided for the study. Kseniya Nikerova revised the language.

\section{References}

Atlas Karel'skoi ASSR, 1989. [Atlas of the Karelian ASSR]. Moscow: GUGK. 40 p.

Butorina, A.K., Cherckashina, O.N., Ermolaeva, O.V., Chernodubov, A.I., Avdeeva, I.A., 2007. Cytogenetic monitoring of the Usmansky and Khrenovskoyautochtonic pine stands. Biology Bulletin, 34 (4): 423-426. https://doi. org $/ 10.1134 / \mathrm{s} 1062359007040152$

Butorina, A.K., Ermolaeva, O.V., Cherkashina, O.N., Mazurova, I.E., Belousov, M.V., Chernodubov A.I., 2008. Perspektivy ispol'zovaniya tsitogeneticheskogo analiza $\mathrm{v}$ lesovodstve na primere otsenki sostoyaniya ostrovnykh borov Voronezhskoi oblasti [Perspectives of using the cytogenetic analysis in forestry from the example of assessment of state of island pine forests (Voronezh region)]. Biology Bulletin Reviews, 128 (4): 400-408.

Butorina, A.K., Kalaev, V.N., 2000. Analysis of sensitivity of different criteria in cytogenetic monitoring. Russian Journal of Ecology, 3: 186-189. https://doi.org/10.1007/ bf02762819

Butorina, A.K., Kalaev, V.N., Mironov, A.N., Smorodinova, V.A., Mazurova, I.E., Doroshev, S.A., Sen'kevich, E.V., 2001. Cytogenetic variation in populations of Scotch pine. Russian Journal of Ecology, 3: 198-202. https://doi.org/10.1023/a:1011366328809

Butorina, A.K., Muraya, L.S., IsaKov, Iu.N., 1979. Spontannyi mutagenez u sosny obyknovennoi (Pinus silvestris L.). Pervyi sluchai obnaruzheniya mutanta s kol'tsevoi i dobavochnoi khromosomami [Spontaneous mutagenesis in Scots pine (Pinus silvestris L.). First case of the detection of a mutant with ring and supernumerary chromosomes]. Reports of the Academy of Sciences, 248 (4): 977-979. 
Carvalho, A., Gaivao, I., Lima-Brito, J., 2020. Seed osmopriming with PEG solutions in seeds of three infraspecific taxa of Pinus nigra: Impacts on germination, mitosis and nuclear DNA. Forest Ecology and Management, 456: 117739. https://doi.org/10.1016/j. foreco.2019.117739

Carvalho, A., Leal, F., Matos, M., Lima-Brito, J., 2018. Effects of heat stress in the leaf mitotic cell cycle and chromosomes of four wine-producing grapevine varieties. Protoplasma, 255: 1725-1740. https://doi.org/10.1007/ s00709-018-1267-4

Daev, E.V., Dukelskaya, A.V., Barabanova, L.V., 2015. Cytogenetic approaches for determining ecological stress in aquatic and terrestrial biosystems. Russian Journal of Genetics: Applied Research, 5 (5): 441-448. https://doi. org/10.1134/s2079059715050056

Ehkologicheskii monitoring. Metody biologicheskogo monitoringa. Chast' 2 [Ecological monitoring. Methods of biological monitoring. Part 2]. Nizhny Novgorod: NNGU. 1995. 272 p.

Geras'Kin, S.A., KuZmenKov, A.G., VASILIYev D.V., 2018. Vremennaya dinamika tsitogeneticheskikh effektov v khronicheski obluchaemykh populyatsiyakh sosny obyknovennoi [Time dynamics of cytogenetic effects in chronically exposed Scots Pine populations]. Radiation Biology. Radioecology, 58 (1): 74-84. https://doi. org $/ 10.7868 / \mathrm{s} 0869803118010083$

Geras'Kin, S.A., Ziminal.M., Dikarev, V.G., Vasiliyev, D.V., Oudalova, A.A., Alexakhin, R.M., Zimina, L.M., Zimin, V. L., Blinova, L.D., 2003. Bioindication of the anthropogenic effects on micropopulation of Pinus sylvestris L. in the vicinity of a plant for the storage and processing of radioactive waste and in the Chernobyl NPP zone. Journal of Environmental Radioactivity, 66 (1-2): 171-180. https://doi.org/10.1016/s0265$931 x(02) 00122-4$

GoryachKinA, O.V., SizyKh, O.A., 2012. Tsitogeneticheskie reaktsii khvoinykh rastenii v antropogenno-narushennykh raionakh g. Krasnoyarska i ego okrestnostei [Cytogenetic reactions of coniferous plants in anthropogenic disturbed areas of Krasnoyarsk and its environs]. Conifers of the Boreal Zone, 1-2: 46-51.

Gromtsev, A.N., Petrov, N.V., 2016. Naibolee uyazvimye lesa severo-zapada taezhnoi zony Rossii: landshaftnye osobennosti, sovremennoe sostoyanie, sokhranenie [Most vulnerable forests of Russia's north-western boreal zone: Landscape characteristics, present day condition, conservation]. Proceedings of the Saint Petersburg Forestry Research Institute, 2: 4-16. https://doi. org/10.21178/2079-6080.2016.2.4

Hizume, M., Kishimoto, K., Tominaga, K., Tanaka, A., 1988. Presence of B-chromosome in Picea glehnil (Pinaceae). Kromosomo, 2 (51-52): 1715-1720.

IL'INSKIKH, N.N., IL'INSKIKH, I.N. NeKRASOv, V.N., 1988. Ispol'zovanie mikroyadernogo testa $\mathrm{V}$ skrininge i monitoringe mutagenov [Use of micronucleus test in screening and monitoring of mutagens]. Cytology and Genetics, 22 (1): 67-72.

IL'INSKikH, N.N., IL'INSKIKH, V.V., VANChUGOVA, N.N., IL'INSKIKH, I. N., 1992. Mikroyadernyi analiz $i$ tsitogeneticheskaya nestabil'nosv' [Micronuclear analysis and cytogenetic instability]. Tomsk: Tomsk State University. $269 \mathrm{p}$.
Ivanter, E.V., Korosov, A.V., 2011. Vvedenie $v$ kolichestvennuyu biologiyu [Introduction to quantitative biology]. Petrozavodsk: Petrozavodsk State University. 302 p.

KalaEv, V.N., 2009. Tsitogeneticheskie reaktsii listvennykh drevesnykh rastenii na stressovye usloviya i perspektivy ikh ispol'zovaniya dlya otsenki genotoksichnosti okruzhayushchei sredy [Cytogenetic reactions of deciduous woody plants to stress conditions and prospects for their use to assess the genotoxicity of the environment]. $\mathrm{PhD}$ thesis. Voronezh: Voronezh State University. $47 \mathrm{p}$.

KALASHNIK, N.A., 2008. Chromosome aberrations as indicator of technogenic impact on conifer stands. Russian Journal of Ecology, 39 (4): 261-271. https://doi.org/10.1134/ s106741360804005x

KUnAKH, V.A., 1995. Genome variability in plant somatic cells. 2. Natural variability. Biopolymers and Cell, 11 (6): 5-40. https://doi.org/10.7124/bc.000400

KunaKh, V. A., 2011. Plastichnost' genoma somaticheskikh kletok i adaptivnost' rastenii [Genome plasticity of somatic cells and plant adaptability]. Molecular and Applied Genetics, 12 (8): 8-14.

KvitKo, O.V., Muratova, E.N., Bazhina E.V., 2011. Cytogenetics of Abies sibirica in decline fir stands of west Sayan High Mountains. Contemporary Problems of Ecology, 4 (6): 641-646. https://doi.org/10.1134/ s1995425511060129

Mashina, E.V., Kalayev, V.N., Muraya, L.S., Lelikova, E.S., 2009. Tsitogeneticheskie reaktsii semennogo potomstva sosny obyknovennoi na kombinirovannoe antropogennoe zagryaznenie $\mathrm{v}$ raione Novolipetskogo metallurgicheskogo kombinata [Cytogenetic response of seed progeny of Scots pine to combined anthropogenic pollution in the area of Novolipetsk metallurgical combine]. Ecological Genetics, 3: 17-29. https://doi. org/10.17816/ecogen7317-29

Mashina, O.S., Tikhonova, I.V., Muratova, E.N., Muraya, L.S., 2012. Tsitogeneticheskie osobennosti semennogo potomstva karlikovykh sosen na Yuge Vostochnoi Sibiri [Cytogenetic features of seed progeny of dwarf pines in the South of Eastern Siberia]. Conifers of the Boreal Zone, 1-2: 127-135.

Muratova, E.N., Sedel'nikova, T.S., 2004. Genomic and chromosomal mutations in Scots pine (Pinus sylvestris L.) growing in extreme conditions. Conifers of the Boreal Zone, 22 (1-2): 128-140.

NemtSeVA, L.S., 1970. Metafaznyi metod ucheta perestroek khromosom [Metaphase chromosome rearrangements accounting method]. Mokva: Nauka. 124 p.

Pardayeva, E.U., Mashkina, O.S., Popov, V.N., 2017. State of Pinus sylvestris L. generative sphere according to cytogenetic analysis in changing climate conditions on the territory of Voronezh oblast. Contemporary Problems of Ecology, 3: 271-276. https://doi.org/10.1134/ s1995425517030088

Pravdin, L.F., Budaragin, V.A., Kruklis, M.V., ShERShUKOVA, O.P., 1972. Metodika kariologicheskogo izucheniya khvoinykh porod [Methods of karyoiogic investigation of Conifers]. Lesovedenie, 2: 67-75.

Prus-Glowacki, W., ChudziŃSKa, E., WojnicKaPóŁtorak, A., Kozacki, L., Fagiewicz, K., 2006. Effects of heavy metal pollution on genetic variation 
and cytological disturbances in the Pinus sylvestris L. population. Journal of Applied Genetics, 47(2): 99-108. https://doi.org/10.1007/BF03194607

Pukhal'skiy, V.A., Solov'ev, A.A., Badaeva, E.D., Yurtsey, V.N., 2007. Praktikum po tsitologii i tsitogenetike rastenii [Practicum on plant cytology and cytogenetics]. Moscow: Kolos. 198 p.

Reis, S., Pavia, I., Carvalho, A., Moutinho-Pereira, J., Correia, C., Lima-Brito, J., 2018. Seed priming with iron and zinc in bread wheat: Effects in germination, mitosis and grain yield. Protoplasma, 255: 1179-1194. https://doi.org/10.1007/s00709-018-1222-4

Sedel'nikova, T.S., Muratova, E.N., Pimenov, A.V., 2010. Variability of chromosome numbers in gymnosperms. Biology Bulletin Reviews, 1 (2): 100-109. https://doi. org/10.1134/s2079086411020083

SluchyK, V., SLUChYK, I., SHYICHUK, A., 2014. Assessment of both environmental cytotoxicity and trace metal pollution using Populus simonii Carr. as a bioindicator. Environmental Monitoring and Assessment, 186 (10): 6645-6650. https://doi. org/10.1007/s10661-014-3879-2

Stimpson, K.M., Matheny, J.E., Sullivan, B.A., 2012. Dicentric chromosomes: Unique models to study centromere function and inactivation. Chromosome Research, 20: 595-605. https://doi.org/10.1007/s10577012-9302-3

TeOH, S.B., ReES, H., 1977. B-chromosomes in White spruce. Proceeding of the Royal Society, 198 (1133): 325-344. https://doi.org/10.1098/rspb.1977.0101

TsvetKov, P.A., 2006. Issledovanie prirody pozharov $\mathrm{v}$ severnoi taige srednei Sibiri [Investigation of the nature of fires in the northern taiga of Central Siberia]. Conifers of the Boreal Zone, 23 (2): 186-195.

TsvetKov, V.F., BrovinA, A.N., 2017. Challenges of forestry in Subarctic European Russia. Russian Journal of Forest Science, 4: 284-292. https://doi.org/10.7868/ S0024114817040040

Vladimirova, O.S., Muratova, E.N., 2005. Kariologicheskie osobennosti eli sibirskoi (Picea obovata Ledeb.) $\mathrm{v}$ usloviyakh antropogennogo zagryazneniya g. Krasnoyarska [Karyological features of Siberian spruce (Picea obovata Ledeb.) under anthropogenic contamination conditions of Krasnoyarsk]. Ecological Genetics, 3 (1): 18-23. https://doi.org/10.17816/ecogen3118-23

Received July 23, 2021 Accepted October, 27, 2021 